\title{
Debt, Corruption and Investment in East Africa: A Panel ARDL Analysis
}

\author{
Millicent Bridgit Aswata, John Bosco Nnyanzi*, John Mayanja Bbale \\ School of Economics, Makerere University, Kampala, Uganda \\ Email:*jbnnyanzi@yahoo.com
}

How to cite this paper: Aswata, M.B., Nnyanzi, J.B. and Bbale, J.M. (2018) Debt, Corruption and Investment in East Africa: A Panel ARDL Analysis. Modern Economy, 9, 2012-2038.

https://doi.org/10.4236/me.2018.912126

Received: November 2, 2018

Accepted: December 7, 2018

Published: December 10, 2018

Copyright @ 2018 by authors and Scientific Research Publishing Inc. This work is licensed under the Creative Commons Attribution International License (CC BY 4.0).

http://creativecommons.org/licenses/by/4.0/

(c) (i) Open Access

\begin{abstract}
We set out to investigate the relationship between public debt and private investment using a panel of four countries in East Africa for the period 1992-2015. The results from the Autoregressive Distributed Lag Models show that Public Debt (PD) crowds out both Private Domestic Investment (PDI) and Foreign Direct Investment (FDI) in the long run, although the magnitude of the impact is greater for the former category. We fail to find evidence of any short run significant relationship in either case. However, the importance of institutional quality in enhancing relationship in question is unquestionably confirmed in the data. The effect of $P D$ on either $P D I$ or $F D I$ is observed to change when the corruption control improves. The immediate recommendation is the need to design fiscal policies to tame the growing debt that appears to discourage private investment in the region. A proper debt management system coupled with clear policies to improve the institutional quality would likely boost private investment in East Africa. The anti-corruption measures already in place should be enhanced to create a conducive investment climate for the private sector to thrive.
\end{abstract}

\section{Keywords}

Public Debt, Private Domestic Investment, Foreign Direct Investment, Corruption, ARDL

\section{Introduction}

The East African countries have ambitious plans to transform their economies to middle income levels in the next decade. In an ardent effort to achieve this target, member countries have for the last decade undertaken public investment in infrastructure as well as investor-friendly strategies including but not limited to investment incentives and institutional enhancements. Intuitively, the strategies aim at creating a private-sector-driven economy. Given the small tax base and 
inadequate revenue characteristic of developing countries and East Africa in particular, the main source of finances in the development and expansion of infrastructure is public debt secured both domestically and externally. While public investment may be complementary to private investment particularly where the former increases capital productivity of the private sector, increases demand for inputs, and improves aggregate demand and savings, the link between public debt and private investment is still an empirical question. In principle, however, since the supply of money is fixed, domestic borrowing by the government may be at the cost of private investment since it will be withdrawn from the productive uses. Limited credit availability offered at high interest rates crowds out the private sector just as increased domestic borrowing may also result into high interest rates that cause an increase in cost of production, making tradable goods expensive and noncompetitive in foreign markets. Regarding these theoretical arguments, the key question still attracting debate is the extent to which public debt would quantitatively impact private investment and via which channels this would be possible. The current paper seeks to appreciate these concerns with reference to East Africa.

Certainly the empirical arena is not in scarcity of studies that examine the issue in question. However, a detailed scrutiny of the available studies informs us of a divergence in the findings. For example, while the likes of inter alia [1] for Senegal, [2] for Bangladesh, and [3], report a crowding in effect of public debt on private investment, the crowding out finding is visible in other studies such as [4]-[9], among others. Yet different schools of thought agree on a non-linear relationship between the variables in question, pointing to a threshold effect. [10] and [11] inter alia, fall under the latter category. However, still among these, differences are not uncommon. For example, while the likes of [10] argue that debt affects private investment up to a threshold level and becomes positive beyond that threshold, the category of [11] argues that public debt first affects private investment positively until a certain threshold beyond which the effect turns out to be negative. Moreover it is not surprising to find studies that appear inconclusive regarding the relationship in question (e.g. [12]).

Perhaps the reasons for the mixture of evidence regarding the debt-investment nexus are not self-explanatory but could have basis in type of debt considered, type of investment examined, sampling, methodology and data used. It appears too that overall; the results depend on the country or region under analysis. We note that there is scanty literature on studies that capture the linkage in question for the east African countries. Yet the region is continuously engaged in achieving greater regional integration and the Eat African monetary union (EAMU) in particular which, via the EAMU Protocol inter alia, requires a ceiling on gross public debt of 50 percent of GDP in net present value terms as one of the four primary convergence criteria ${ }^{1}$ According to [13], the share of government debt

${ }^{1}$ The other three primary convergence criteria are: a ceiling on headline inflation of eight percent; reserve cover of 4.5 months of import; and, a ceiling on the overall deficit of three percent of GDP, including grants. All the four must be must be attained and maintained by each Partner State, for at least three years, before joining the Monetary Union. 
as a proportion of GDP for the EAC member states increased between 2012 and 2016 with Kenya leading in terms of debt accumulation, followed by Tanzania, Rwanda and Uganda. Kenya's share of $P D$ as a proportion of GDP increased from 20.5 per cent in 2007 to 31.13 per cent in 2014, while Tanzania's grew from 28.03 per cent to 33.21 per cent in the same period. On the other hand, Rwanda's stood at 31.13 in per cent from 18.93 per cent while Uganda's expanded to 31.21 per cent in 2014, up from 22.08 per cent in 2007. Although, during the year 2016, all the East African countries had debt to $G D P$ ratios below 50\% of $G D P$ with the exception of Kenya whose debt to GDP ratio was above the ceiling of $50 \%$ of $G D P$, debt sustainability is a key issue partly due to its direct or indirect effects on other key variables including but not limited to private investment.

With the aim of harnessing the private investment potential to promote economic growth and development in the region, the five partner states of the East African Community (EAC) agreed to cooperate in the areas of investment and industrial development [14] as outlined in the EAC Treaty (Chapter 12, Articles 79 and 80). The governments finance the activities of the EAC and each has a Ministry of EAC to coordinate and facilitate the activities of the common market. The cooperation that has been further enhanced by the coming into force of the EAC Protocol, seeks to rationalize investments with a view of achieving balanced and sustainable growth besides promoting the EAC as a single investment area.

Figure 1 provides a trend analysis of the averages of Private Domestic Investment $(P D I)$ and Public Debt $(P D)$ for the four countries (Kenya, Rwanda, Tanzania and Uganda) under the study to give a general overview of the region. As evident, the Public debt in early 1990s was above 80 percent of GDP and began declining in 1996 and reached about 79 percent in 2002. The average Private Domestic investment over this period fluctuated between 20 and 19 percent.

A country specific comparison, from Figure 2, indicates that Public Debt levels were over 50 percent of GDP in early 1990s in all the EAC countries under study, with Tanzania recording the highest debt level at 128 percent, followed by Uganda at 119 percent. Kenya and Rwanda had 54 percent and 52 percent debt as percentage of GDP respectively, in the same period. Note that Tanzania and Rwanda qualified for debt relief under the enhanced Heavily Indebted Poor Countries (HIPC) initiative. As a result, Tanzania's Debts worth over $\$ 6$ billion were canceled following implementation of the Paris Club 7 Agreement. This explains the low debt levels of 21.52 percentage of GDP in 2008 and 27.84 percent of $G D P$ in 2011 for Tanzania. In Rwanda, the HIPC initiative was launched in 1996.

From Figure 2, it is noted that $P D I$ has however been fluctuating in all the EAC countries, despite policies aimed at promoting investment. The highest levels of PDI recorded were 33.24 percent in 2011 (Tanzania), 27.06 percent in 2011 (Uganda), 22.5 percent in 2011(Kenya) and 26.36 percent in 2011 (2015).

On the other hand, the EAC Region recorded the highest share of foreign direct investment (FDI) across the continent, achieving $26.3 \%$ of total projects 


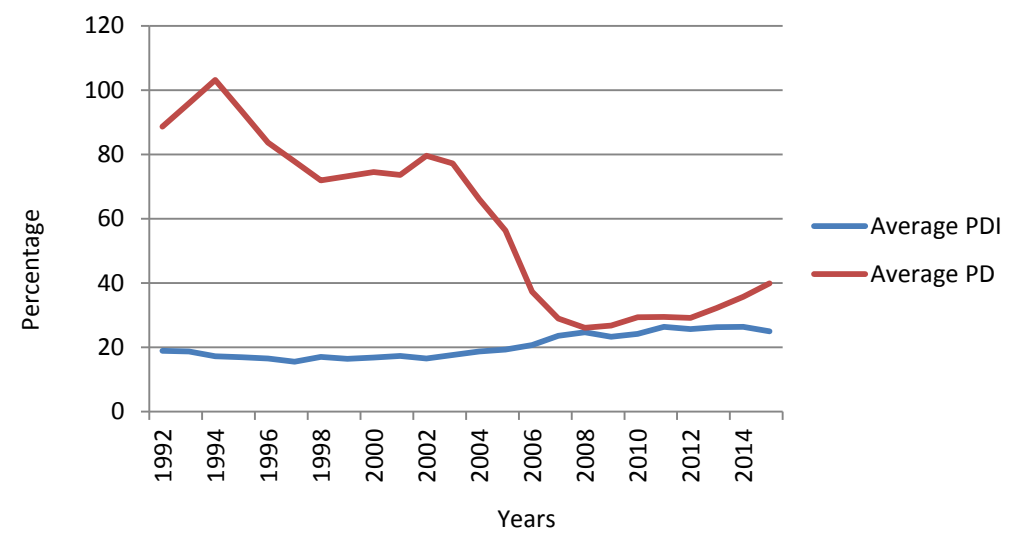

Figure 1. Averages percentages of public debt and private investment for the EAC countries (1992-2015). Source: Based on World Bank world development indicators dataset.
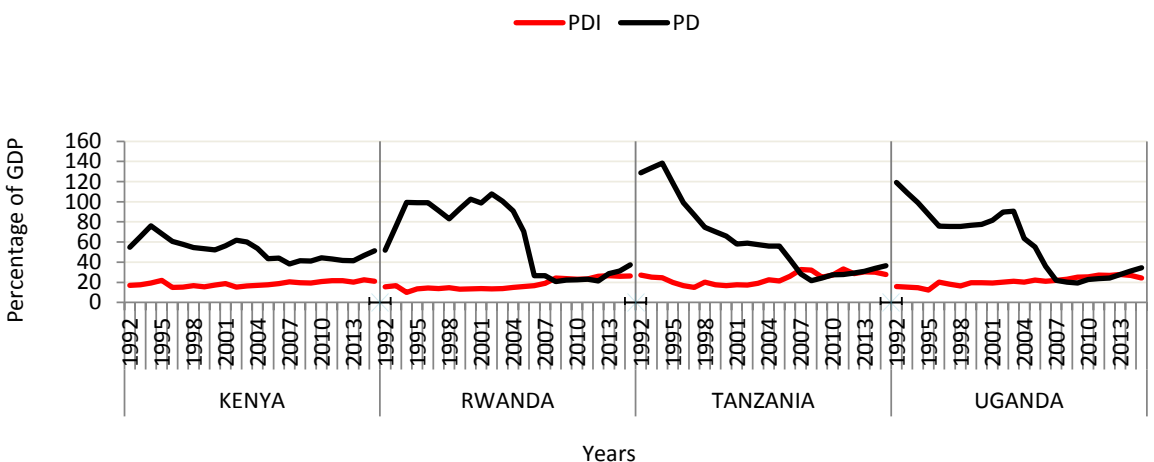

Figure 2. Country specific trend analysis of public debt versus private domestic investment in EAC for the period 1992-2015. Source: Based on World Bank world development indicators dataset.

with Kenya being among the region's major beneficiaries [15]. FDI, is considered vital for economic development of capital scarce countries, as it provides not only financial assistance but also capital, technology, new jobs, management skill and expertise [9]. In Figure 3, FDI was less 1 percent of $G D P$ in early 1992 in Uganda, Kenya, Tanzania and Rwanda and began to slightly increase. Uganda has had the highest percentage compared to the rest throughout the period under study. In 1998, FDI as a percentage of GDP stood at 3.1 in Uganda, followed by Tanzania (1.8), Rwanda (0.3) and Kenya (0.1). In 2007, as a percentage of GDP, FDI increased to 6.4 in Uganda; 2.7 in Tanzania; 2.2 in Kenya and 2.1 in Rwanda. From this period the trend has been fluctuating and declined to 3.8 percent GDP in Uganda; increased in Tanzania to 4.3 percent. In Kenya it increased slightly to 2.67 percent while in Rwanda it increased to 3.99 percent.

In light of the above facts at hand, the popular question is the extent to which public debt affects domestic investment here categorized in form of private domestic investment and foreign direct investment. The current paper attempts to offer contribution to the debate. In theory, the purported relationship is certainly well-grounded. For example, whereas $P D$ could be used for some public 


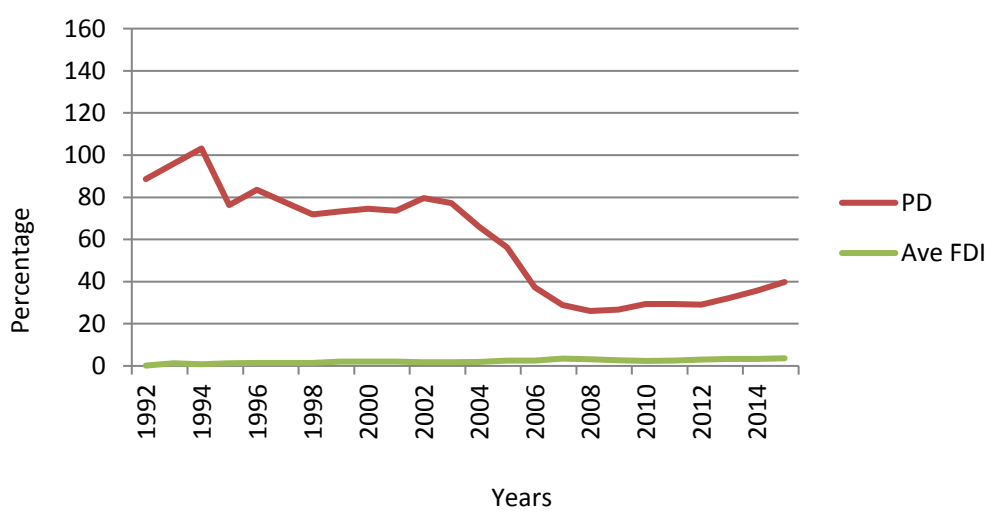

Figure 3. Trend analysis of percentage averages of $F D I$ versus $P D$ in east africa. Source: Based on World Bank world development indicators dataset.

investment that compliments private investment, prudent and sustainable debt management is imperative because a continual rise of domestic debt causes interest rates to soar and crowd-out private investors and annual interest increments on external debt could exceed all other spending [13]. Moreover, debt overhang in the long run discourages private investment due to perceived higher tax burdens. Additionally, poorly done public investment, such as poor infrastructure, would increase the cost of doing business and discourage investors. Therefore, there is need for efficiency in execution of public financed projects. The financing of public sector investment, however, whether through taxes, issuance of debt instruments, or inflation, can reduce the resources available to the private sector and thus depress private investment activity.

We focus our study on three specific objectives. First is to investigate the effect of public debt on the level of private domestic investment. Second, we examine the impact of Public Debt on Foreign Direct Investment. Lastly, we analyze the impact of institutions on Private Investment. The latter objective is grounded in the argument that the perception of the institutional quality may, in addition to, inter alia the fear of prudent debt management and sustainability, and, debt overhang, impact on private investment. Specifically, institutional quality might reduce economic uncertainties, determine the ease of establishment and doing business and ensure efficient utilization of resources to avoid unsustainable debt levels in the public sector. By implication, sound and efficient institutions are likely to enhance good governance which is a cornerstone to efficient resource allocation and utilization. On the other hand, bad institutional quality such as corruption would likely lead to inefficiency in government spending, poor tax administration, misallocation of resources and embezzlement. With weak institutions in place, public borrowing may continue to increase to fund the ever increasing public expenditure on ineffective administration. The consequence might be an increase in the production costs (for example, poorly done infrastructure), which discourages private investment. According to the World Economic Forum [16], weak institutions remain one of the major challenges affecting not only East Africa countries but also Sub-Saharan Africa as a whole. Yet, as 
the authors assert, the legal and institutional framework within which economic agents interact would determine competitiveness, and influence decisions whether to or not to invest as well as how benefits/costs associated with development strategies and policies are distributed in an economy. However, it is not illogical to argue that some countries experiencing bad institutional quality could as well attract foreign investment on basis of other reasons, say, the presence for scarce minerals.

In East Africa, member countries have put in place ethics and anti-corruption institutions in order to improve governance quality. According to World Governance Indicators of 2015, Rwanda is ranked highly on the corruption control measure, scoring 70 per cent, followed by Kenya at 53 per cent, Tanzania with 36 per cent and Uganda with 20 per cent. Given the aforementioned theoretical perspective to institutions vis-a-vis the ease of doing business, it is important to establish the extent to which institutional quality would influence the relationship between public debt and private domestic investment.

Overall, the results provide evidence of the detrimental role played by public debt in private investment in the long run. The crowding-out impact however is much significantly felt for Private Domestic Investment in relation to Foreign Direct Investment. We fail to find evidence of any short run significant relationship in either case. However, the importance of institutional quality in enhancing relationship in question is unquestionably confirmed in the data. The effect of $P D$ on either $P D I$ or $F D I$ is observed to change when the corruption control improves. These findings have implications for policy.

The rest of the paper is organized as follows. In the next section, a detailed analysis of both theoretical and empirical literature is presented. This is followed by Section 3 where the model and data are discussed. We then present and discuss our results Section 4, and conclude in Section 5.

\section{Literature}

\subsection{Theoretical Overview}

Investment models usually distinguish two separate elements in the investment process: the determination of a desired capital stock and the specification of an adjustment process by which the gap between existing and desired capital stock is filled [17].

One such model that hold relevancy to our study is the accelerator theory that can be traced back to [18], where he explained that demand for capital depends on the acceleration of demand of a finished product. Since Clark focused on quantity as opposed to price, his model was regarded as being 'Keynesian' in spirit and has been referred to as the rigid or simple accelerator model of investment [19]. While the rigid accelerator model explains investment as a function of output growth only and assumes that the desired stock of capital is attained in each time period, its counterpart, the flexible accelerator model came later as a result of reformulating the rigid model to take into account the influence on in- 
vestment of uncertainty, profits, financial factors and other variables [20]. Details of the model are given in the methodology section.

Besides the accelerator theory, we acknowledge existence of other theories to explain investment. For example, Jorgenson's [21] model of investment, also known as Neoclassical Model of Investment is an alternative to the accelerator model. Jorgenson assumes that firms maximize profit subject to a Cobb-Douglas production technology. Investment is considered a distributed lag function of the changes in the desired capital, where the desired capital is a function of the level of output, price of output and the user cost of capital. As such, investment becomes a function of the firm's output and the user cost of capital. It is notable however that the neoclassical model suffers from several restrictive assumptions, such as rational expectations (although lags have been introduced in variants of the model to capture adaptive expectations), unitary elasticity of substitution between capital and labor, exogenously determined output prices, reversible investment, malleable stock of capital (factor input ratios of equipment carried over from the previous period can be changed to minimize production costs), and constant cost of capital (discount rate).

On the other hand, Tobin's q-theory extends the neoclassical theory by incorporating adjustment costs to account for losses in output. In addition to postulating that investment depends upon the ratio of the market value of a firm's assets to their replacement cost, i.e. the q-ratio [22], the model uses the shadow price of capital services, referred to as the user cost of capital, to define the optimal level of capital stock, which implies a high degree of perfection in the capital markets. In essence, the theory contends that as firms maximize the present value of their profits, capital stock will adjust accordingly until no more profits can be made [23]. Consequently, the increase in capital is through investment, while a decrease is through depreciation.

The current study adopts the Accelerator Model which appears to have more relevance to the developing country setting where the underdeveloped equity and bond markets are part and partial of the economies. Other models seem to lack this attribute. For example, the Tobin Q theory of investment has been criticized for oversimplifying rational expectations and efficient markets, and the possibility of generating different investment behavior from the specification of the firm's alternative objective and production function [23]. Moreover, as argued by critics, a model attributed to Jorgensen equally suffers from several restrictive assumptions running from rational expectations, unitary elasticity of substitution between capital and labor, exogenously determined output prices, and constant cost of capital among others ${ }^{2}$.

\subsection{Empirical Literature}

It has been pointed out earlier that the field under analysis is not in scarcity of empirical references. Interestingly however, are the divergent findings on effects

${ }^{2} \mathrm{~A}$ detailed analysis of the theories of investment can be found in [24]. 
of public debt on private investment. The different estimation techniques, variations in the datasets used, the sample space, as well as the varied indicators for debt and investment would perhaps account for the observed divergences in the findings, although we also admit that alternative explanations would be elsewhere. The various schools of thought nevertheless appear to rotate around four strands of literature: those in support of the crowding-out role; those for the crowding-in effect; those that are inconclusive; and, those arguing for a non-linear relationship with focus on the threshold effect.

To begin with, in demonstrating crowding out effect, using growth accounting [5], using a panel of 38 advanced and emerging economies between 1970 to 2007, show that the adverse effects on growth of initial debt largely slows down labor productivity growth as a result of reduced investment which reduces growth of capital per worker. A similar finding can be found in [25], who, in their study with focus on the North African countries, report a negative relationship between debt service and economic growth through its adverse effect on investment and export multiplier for all the countries they tested. Still in the same vein [12]), using OLS, found out that $P D$ decreased $P I$ in a study on Public Debt's impact on growth, investment and unemployment in Pakistan. A study on the same country Pakistani for the period 1981 to 2007 was carried out by [9]. The results out of the OLS estimate uncover a discouraging role of $P D$ in FDI.

Support for the crowding-out effect can further be located in a study by [6], where he uses a novel data for local public debt issuance for China during the period 2006-2013. The results show that local public debt issuance crowded out investment by private manufacturing firms by tightening their funding constraints. An earlier study by [8] for Nigeria with focus on private sector investment yields similar outcomes. Relatedly [26], in their study on Nigeria, using Multiple Regressions, found an inverse relationship between external debt and investment volume during for the period spanning from 1980 to 2008. A crowding-in-effect is likewise found by [1] in the case of Senegal. Similar studies on individual East African countries have likewise provided support for the crowding-out role of public debt to investment. For example [27], in a study on Kenya, using the co-integration technique, found that debt service ratio negatively influenced private investment. The "debt overhang effect" is likewise found in [28] who uses a similar methodology but for the analysis of Kenyan data during the period 1967-2007. Still, with focus on Kenya during another period from 1980 to 2013 [29], using Granger causality, established not only a unidirectional causality from debt using Granger causality test, but also a negative debt-effect on Private Investment.

The other school of thought identifiable from the empirics includes protagonists for the crowding-in effect of debt on private investment. For example, [4] uses Unit Root test and co-integration in investigating the effect of public borrowing on Private Investment in Pakistan, between the fiscal years 1971/72 and 2005/06 to provide evidence of a crowd in effect. In his view, the result is attributable to sustainable debt levels, excess liquidity in Banking system, and, ex- 
penditure on goods with positive externalities. Similarly, [2] employs the co-integration and error correction model techniques to establish a crowd in effect of public debt on private investment in Bangladesh, for the period from 1976 to 2006. Elsewhere in [3], focus is shifted to South Africa and FDI during the period 1983 to 2013, Here, the authors, using Vector Error Correction Model, likewise find a positive relationship between $P D$ and $F D I$ in the Long Run. Further support for the crowding-in effect can be found in a study on Sri Lanka by [30] where the Vector Error Correction Model (VECM) was estimated on data spanning from 1978 to 2015. [31] concurs with the latter author but only in the case of external debt. In their finding, external debt crowds in domestic investment in the long run.

The third strand of literature consists of categories of authors that provide inconclusive evidence on the relationship in question. For example, the second analysis of the aforementioned study by [6] indicates that local public debt issuance did not affect state-owned and foreign firms in China during the period 2006-2013. Similarly [32], did not find any evidence of debt overhang nor crowding-out effect in Bangladesh in the short run.

Beside the three strands presented above, we can also point out that other studies that argue for nonlinearity of the model that produces varying results depending on the threshold level of public debt. In this category, we identify among others, a study by [10]. Here the authors employ a panel of 10 African economies using data from 1981 to 2010. The results from the panel threshold regression confirm the significance of the nonlinear relationship between public debt and domestic investment in the Long Run. Specifically, the findings indicate that any public debt levels lower than 47.31 percent of GDP are positively associated with domestic investment, whereas beyond this public debt threshold, the relationship between public debt and investment becomes negative. Similarly [11], using instrumental variable as well as bootstrapping techniques found out a long run positive impact of domestic debt on private investment in Nigeria from 1981 to 2012. However, in a further analysis, the authors show that the relationship between external debts and private investment in Nigeria is U-shaped. Specifically, the results indicate that the relationship between external debt and private investment is negative up to a threshold level, and becomes positive beyond the threshold level.

We have earlier on argued that the role of institutions in the perceived link between public debt and private investment is theoretically plausible. The empirical arena however, is still characterized by scarcity in terms of related studies. A few available scholarly works focus on the direct effect of individual as well as aggregate institutions on private investment. The results re however still mixed up. For example, while the likes of [33] and [34] find an adverse impact of corruption on $F D I$, others such as [35] report a detrimental effect.

\section{Literature Gap}

In sum, empirical literature provides mixed results and calls for further debate 
regarding the issue in question. The importance of institutions in the debt-investment nexus is theoretically plausible but generally ignored in the existing literature. We focus on the East African Community as a region overly neglected in the existing analysis regarding the area under discussion. Yet, as alluded to earlier, in her efforts to integrate into a monetary union and to further consolidate her gains in terms of private sector investment with a dream to make it an engine of growth, the region urgently needs evidence-driven policies relevant for the member countries. Our main contribution pertains not only to adding to the pool of literature in the field but also to examine for the first time in the east African studies the quantitative role of corruption in channeling the effect of public debt on private investment.

\section{Model and Data}

\subsection{Theoretical Framework and Model Specification}

As presented earlier, the current study adopts the Flexible Accelerator Model with a few extensions because it takes into account uncertainty common to developing economies. According the model, Capital is adjusted towards its desired level hence firm net investment is proportional to change in desired capital. Demand for capital increases when demand for output increases, hence the name accelerator model [36]. The model assumes that

$$
K p_{t}^{*}=\alpha Y_{t}^{e}
$$

where: $K p_{t}^{*}$ stands for desired stock of capital by private sector in period $t$ $\alpha Y_{t}^{e}$ is the expected level of output in period $t$.

Following [20], when the adjustment mechanism is introduced, then actual private capital adjusts to the difference between the desired private capital in period $t$ and actual private capital in the previous period $(t-1)$ :

$$
K p_{t}-K p_{t-1}=\beta\left(K p_{t}^{*}-K p_{t-1}\right), \quad 0 \leq \beta \leq 1
$$

Simplifying Equation (2) by making $K p_{t}$ the subject, we obtain:

$$
K p_{t}=\beta K p_{t}^{*}+(1-\beta) K p_{(t-1)}, \quad 0 \geq \beta \leq 1
$$

where:

$K p_{t}$ is the actual stock of private capital while $\beta$ is the coefficient of adjustment. For estimation purposes the study specified a partial adjustment function by using the Gross Domestic Private Investment $\left(P D I_{t}\right)$ and $\left(F D I_{t}\right)$ rather than the private capital $\left(K p_{t}\right)$ due to lack of data on capital stock in most of the developing countries. Hence the gross Private Domestic Investment is given by:

$$
P D I_{t}=\left(P D I_{t}-P D I_{t-1}\right)+\delta P D I_{t-1}
$$

where: $P D I_{t}$ is the private domestic investment while $\delta$ is the depreciation rate of private capital stock (in this case, the private domestic investment). Equation (3) states that the gross private domestic investment is composed of the net and 
replacement components with the former component equal to the changes in capital stock while the latter is the capital stock available at the previous period. Suppose $P D I$ depends on the desired and the past gross private investment, we re-write Equation (3) to obtain:

$$
P D I_{t}=\beta P D I_{t}^{*}+(1-\beta) P D I_{t-1}, \quad 0 \leq \beta \leq 1
$$

where $=P D I_{t}$ is already defined while $P D I_{t}^{*}$ represents the desired gross private domestic investment in the steady state. However, in the steady state, gross private domestic investment is given by:

$$
P D I_{t}=[1-(1-\delta) L] P D I_{t}^{*}
$$

where, $P D I_{t}^{*}$ means that the desired capital stock is related to the expected level of output such that $P D I_{t}^{*}=Y_{t}^{e}$. L stands for the Lag operator defined as $L Y_{t}^{e}=Y_{t-1}^{e}$, while $\delta$ stands for the depreciation rate of capital stock. Hence after making all the necessary substitutions and then by combining Equations (5) and (6) we get:

$$
P D I_{t}=\alpha \beta[1-(1-\delta) L] Y_{t}^{e}+(1-\beta) P D I_{t-1}
$$

Assuming that $P D$ and other relevant variables denoted by vector $X$ affect the speed of adjustment which determines the closure of the gap between the desired and actual gross Private Domestic Investment in each period. The coefficient $\beta$ will hence vary with the factors that influence Private Domestic Investment and FDI. Hence if $P D$ complements $P D I$, it speeds up the adjustment of the actual investment to the desired level of private investment and vice versa. Hence the speed of adjustment $\beta$ is written in a linear form as:

$$
\beta=b_{0}+\left[\frac{b_{1} P D_{t}+b_{2} X_{t}}{P D I_{t}^{*}-P D I_{t-1}}\right]
$$

where $b_{0}$ is the intercept, $b$ are the coefficients to be estimated, and $X_{t}$ is a vector of other relevant variables that may affect PDI. Substituting Equation (7) into Equation (8) and then re-arranging we obtain:

$$
P D I_{(t)}=b_{0}[1-(1-\delta) L] Y_{t}^{e}+b_{1} P D_{i} t+b_{2} X_{i} t+\left(1-b_{0}\right) P D I_{(t-1)}
$$

However Equation (9) cannot be estimated because it contains some variables that are unobserved, $Y_{t}^{e}$, as well as depreciation rate, $\delta$, whose data in SSA is lacking [20]. Therefore assuming that the depreciation rate is set equal to zero per cent, the model can be expressed in a general way as:

$$
P D I_{i t}=\alpha_{1} P D I_{i t-1}+\alpha_{2} P D_{i t}+\beta^{\prime} X_{i t}+v_{i}+u_{i t}
$$

where, $P D I_{i t}$ is the private domestic investment; $P D I_{i t-1}$ is the private domestic investment for the previous period; $\alpha$ is the coefficient for past gross private investment and $P D ; \quad \beta^{\prime}$ are the coefficients to be estimated; $i=1, \cdots, N$ and $t=1 \cdots, T$ stands for countries and time periods respectively; $v_{i}$ are unobserved country effects and $u_{i t}$ is the error term. Year fixed effects are controlled for in Equation (10). 
To simplify Equation (10) for estimation purposes, few variables are selected in place of $X_{i t}$. The choice of variables of interest is informed by the economic theory which stipulates that as the economy grows, per capita incomes and domestic savings grow, therefore enabling credit creation for private investment. Additionally, improved institutional quality is a pre-requisite for $P D I$ to thrive. Also, since the capital markets are underdeveloped in the least developed and developing economies, most enterprises access finance from the financial markets. This would hence imply that the cost of capital (real interest rate) determines the demand for capital and levels of investment. Finally, Foreign Direct Investment could also positively impact $P D I$ through technology transfers and human capital development.

The variables chosen are hence $P D, G D P$ growth, credit available to private sector $(C P)$, Real Interest rate (RINT), Corruption Control $(C O R)$ and FDI to obtain the following equation:

$$
\begin{aligned}
P D I_{i t}= & \alpha_{1} P D I_{i t-1}+\alpha_{2} P D_{i t}+\alpha_{3} G D P_{i t}+\alpha_{4} C P_{i t}+\alpha_{5} R I N T_{i t} \\
& +\alpha_{6} C O R_{i t}+\alpha_{7} F D I+\mu_{i t}
\end{aligned}
$$

where: $G D P_{i t}$ is the Gross Domestic Product; $C P_{i t}$ is the credit to private sector; $R I N T_{i t}$ is the interest rate; and, $C O R_{i t}$ is the corruption control index.

In addition to $P D I$ model specification, the study also estimated the impact of $P D$ on $F D I$ using the following equation:

$$
\begin{aligned}
F D I_{i t}= & \kappa_{1} F D I_{i t-1}+\kappa_{2} P D_{i t}+\kappa_{3} P D I_{i t}+\kappa_{4} G D P_{i t}+\kappa_{5} H C_{i t}+\kappa_{6} \text { Trade }_{i t} \\
& +\kappa_{7} I N F_{i t}+\kappa_{8} C O R_{i t}+\mu_{i t}
\end{aligned}
$$

where: $F D I_{i t}$ is the Foreign Direct Investment for period $t ; F D I_{i t-1}$ is the Foreign Direct Investment for the previous period; $G D P_{i t}$ measures growth in Gross Domestic Product of the host country; TRADE $E_{i t}$ measures the trade openness of the host country; $I N F_{i t}$ is the inflation rate measured by the GDP deflator; $\mathrm{COR}_{i t}$ is the corruption control.

To evaluate the complementarily between $P D$ and some policy variables in stimulating $P D I$ and $F D I$, we interact $P D$ with corruption index. By interacting $P D$ with corruption index $(P D \times C O R)$ the argument is that the impact of $P D$ on $P D I$ and $F D I$ might be lower if there is good governance and hence low corruption levels.

$$
\begin{aligned}
P D I_{i t}= & \alpha_{1} P D I_{i t-1}+\alpha_{2} P D_{i t}+\alpha_{3} G P D_{i t}+\alpha_{4} C P_{i t}+\alpha_{5} R I N T_{i t} \\
& +\alpha_{6} C O R_{i t}+\alpha_{7} F D I_{i t}+\alpha_{8} P D_{i t} * C O R_{i t}+\mu_{i t} \\
F D I_{i t}= & \kappa_{1} F D I_{i t-1}+\kappa_{2} P D_{i t}+\kappa_{3} G D P_{i t}+\kappa_{4} H C_{i t}+\kappa_{5} P D I_{i t} \\
& +\kappa_{6} T r a d e_{i t}+\kappa_{7} I N F_{i t}+\kappa_{8} P D_{i t} * C O R_{i t}+\mu_{i t}
\end{aligned}
$$

where: $H C_{i t}$ is the human capital Development; $P D_{i t} * C O R_{i t}$ is the interaction term showing the indirect effect of $P D$ on $P D I$ via corruption.

The marginal impact of $P D$ on $P D I$ in the presence of corruption would for example be captured by differentiating Equation (11) with respect to $C O R$ to get: 


$$
\frac{\partial P D I_{i t}}{\partial P D_{i t}}=\alpha_{2}+\alpha_{8} C O R_{i t}
$$

From Equation (15), if $\alpha_{8}<0$, and the absolute value exceeds $\alpha_{2}>0$ it implies that a one percentage point increase in $P D$ yields a negative impact on $P D I$ as corruption decreases. Conversely, if $\alpha_{8}>0, P D$ increases $P D I$ if corruption levels decrease with it. The interaction term between $P D$ and corruption in Equations (13) and (14) test if the rise in $P D$ is as a result of increased corruption levels in the countries under review and whether it lowers or increases PDI or FDI.

Additionally, according to the crowding out hypotheses, the accumulation of a large debt may stifle economic growth through lower investment. On this basis, we assume that public debt would be beneficial to investment up to a certain threshold. Once debt surpass this threshold, it will start to be a constraint to investment. Therefore in order to check for the Public Debt sustainability threshold or to determine the $P D-G D P$ ratio turning point, we introduce a nonlinear relationship between public debt and domestic investment, as in [10] and [11] inter alia. Intuitively, nonlinearity implies that the debt effect on investment is conditioned by the level of public debt. Hence, the following model is run:

$$
P D I_{i t}=\theta_{0}+\theta_{1} P D_{i t}+\theta_{2} P D_{i t}^{2}
$$

where $P D_{i t}^{2}$ is the Public Debt Squared. The inclusion of the squared variable affords us the opportunity to investigate the non-linearity effect of public debt on private investment, as well as analyzing the values of public debt thresholds. As in [37] and [38] we calculate the thresholds only when both coefficients of debt and debt squared are statistically significant. Taking the first order conditions, Equation (16) turns out to be:

$$
\begin{gathered}
\frac{\partial P D I_{i t}}{\partial P D_{i t}}=\frac{\partial\left(\theta_{0}+\theta_{1} P D_{i t}+\theta_{2} P D_{i t}^{2}\right)}{\partial P D_{i t}} \\
0=\theta_{1}+2 \theta_{2} P D_{i t} \\
\Leftrightarrow P D_{i t}(\text { threshold })=\frac{-\theta_{1}}{2 \theta_{2}}
\end{gathered}
$$

Equation (18) is the debt-GDP ratio turning point or the threshold level of debt. Here, $\theta_{1}$ is the coefficient of the linear term and $\theta_{2}$ is the coefficient of the quadratic term.

\subsection{Estimation Technique}

Since it is likely that investment in previous periods could affect current investments, and that the explanatory variables could be endogenous, estimating our model with static techniques would be inappropriate and lead to inconsistent outcomes. Various techniques can be used in such circumstances, among which dynamic panel ARDL, and the system Generalized Method of Moments is (GMM) by [39] have received much popularity but not with small samples in the latter case. The GMM technique is suitable when we have $\mathrm{N}$ greater than $\mathrm{T}$ [40]. 
Otherwise the method could suffer from small sample bias and also lead to the loss of degrees of freedom as observations decrease. Therefore, since the panel consists of a large T (24 years) and a small N (4 countries), the Autoregressive Distributed Lag model (ARDL) would be appropriate. Moreover, the approach performs quite relatively well under circumstances where mixed integration of order zero, I (0) and order one, I (1), exist. But also we suspect endogeneity in our model. According to [41] the ARDL estimation is possible not only where we have a lagged dependent variable as an explanatory variable but also when the explanatory variables are endogenous. The added advantage of the technique is that it offers the long and short-run results simultaneously, removing problems associated with omitted variables and autocorrelation. According to the likes of [42] [43] [44] and [45] inter alia, the estimates obtained from the ARDL method of co-integration analysis are unbiased and efficient, since they avoid the problems that may arise in the presence of serial correlation and endogeneity For these reasons, we opt for the ARDL approach for our study.

Expressing our model in an ARDL framework, we get:

$$
\begin{aligned}
\Delta P D I_{i t}= & \alpha_{0}+\alpha_{1} P D I_{i t-1}+\alpha_{2} P D_{i t-1}+\alpha_{3} G D P_{i t-1}+\alpha_{4} C P_{i t-1} \\
& +\alpha_{5} R I N T_{i t-1}+\alpha_{6} C O R_{i t-1}+\alpha_{7} F D I_{i t-1}+\alpha_{8} P D^{*} C O R_{i t-1} \\
& +\beta_{1} \sum_{i=0}^{m} \Delta P D I_{i t-1}+\beta_{2} \sum_{i=0}^{n} \Delta P D_{i t-1}+\beta_{3} \sum_{i=0}^{p} \Delta G D P_{i t-1} \\
& +\beta_{4} \sum_{i=0}^{q} \Delta C P_{i t-1}+\beta_{5} \sum_{i=0}^{r} \Delta R I N T_{i t-1}+\beta_{6} \sum_{i=0}^{s} \Delta C O R_{i t-1} \\
& +\beta_{7} \sum_{i=0}^{y} \Delta F D I_{i t-1}+\beta_{8} \sum_{i=0}^{z} \Delta P D^{*} C O R_{i t-1}+u_{i t} \\
\Delta F D I_{i t}= & \alpha_{0}+\alpha_{1} P D_{i t-1}+\alpha_{2} G D P_{i t-1}+\alpha_{3} H C_{i t-1}+\alpha_{4} T R A D E_{i t-1} \\
+ & \alpha_{5} C O R_{i t-1}+\alpha_{6} I N F_{i t-1}+\alpha_{7} P D^{*} C O R_{i t-1}+\beta_{1} \sum_{i=0}^{e} \Delta P D_{i t-1} \\
+ & \beta_{2} \sum_{i=0}^{f} \Delta G D P_{i t-1}+\beta_{3} \sum_{i=0}^{g} \Delta H C_{i t-1}+\beta_{4} \sum_{i=0}^{h} \Delta T R A D E_{i t-1} \\
+ & \beta_{5} \sum_{i=0}^{j} \Delta C O R_{i t-1}+\beta_{6} \sum_{i=0}^{k} \Delta I N F_{i t-1}+\beta_{7} \sum_{i=0}^{l} \Delta P D * C O R_{i t-1}+u_{i t}
\end{aligned}
$$

The ARDL panel model offers two estimators: The Mean Group Estimator (MG) and the Pooled Mean Group (PMG). The MG suggested by [46], involves estimating separate regressions models for each country and then derives the long run coefficients as averages of each country. The MG estimator allows both short run and long run coefficients among countries to vary and does not impose restrictions on the coefficients to remain the same. This is because policies and response to shocks may vary among countries. On the other hand, the PMG Estimator involves pooling and averaging of individual regression coefficients. Contrary to MG, PMG estimator allows the short run coefficients including intercepts, speed of adjustment to the long run equilibrium values and error term to vary across countries, while the long run slope coefficients are restricted to be homogenous. Short run coefficients, including intercepts, the speed of adjustment to the long run equilibrium values and error variances are heterogeneous across countries due to different impact of vulnerability to external shocks, fiscal policies and financial crises. On the other hand, long run results remain same 
across countries. PMG is especially useful when there are reasons to expect that the long run equilibrium between variables is similar across sections. The validity of PMG requires that the existence of a long run relationship among the variables of interest requires. In order to determine the choice of an estimator for the panel ARDL model, we use the Hausman test which says that once the p-value is greater than 5\% then PMG will be the preferred model.

However, before the estimation of the co-integration relationship, the ARDL model requires that variables are stationary at level, at first difference or variables are stationary at both level and first difference. The technique may not work in cases where variables are stationarity at second difference. For purpose of checking for stationarity therefore, the study adopted the two unit root test: the Levin, Lin and Chu (LLC) Test which assumes that there is a common unit root process so that the autoregressive coefficients are identical across countries; and, the Im Pesaran and Shin (IPS) Test which allows for individual unit root processes and hence heterogeneous autoregressive coefficients across countries.

\subsection{Data}

The study is based on the EAC involving Kenya, Uganda, Tanzania and Rwanda leaving out Burundi and Southern Sudan due to unavailability of data, for the period under study. To some extent thee EAC countries are homogenous in terms of general policies on investment for implementation in the common market. Panel secondary data used covers the period from 1992 to 2015. The period is selected based on the availability of data. Note also that during this period these countries appear to have developed strategies and policies to promote good governance as well as private and foreign investment. It is also observed that the corruption levels in the region were increasing during this period despite the anti-corruption measures in place. Moreover, during this period, the IMF and World Bank came up with concessional facilities for HIPCs to augment their development prospects.

Table 1 displays the definition of variables used plus the source of data. Descriptive statistics and the pairwise correlation of the variables can be found in Table 2 and Table 3 respectively.

The Private Domestic Investment ranges between 9.983 and 33.24, indicating that 5.098 of the values deviate from the mean. The mean of the Private Domestic Investment is closer to the maximum, hence negatively skewed. The $P D$ as a percentage of $G D P$ ranges between 19.19 with a deviation of 30.15 from the mean. FDI ranges between 0 and 6.48 with a deviation of 1.82 . Similarly, the correlation matrix, in Table 2 shows that most of the variables have optimum linearity and hence the study is relevant. This is because all the values are less than 0.8 (threshold used to establish absence of collinearity problems). However, it is noted that Inflation (INF) and Real Interest Rate (RINT) are highly correlated but since the two variables were each used for two different models, they do not interfere with the results. 
Table 1. Definition of variables and data sources.

\begin{tabular}{|c|c|c|}
\hline Variable & Definition & Source \\
\hline$P D I_{i t}$ & $\begin{array}{l}\text { Private Domestic Investment, Measured by Gross fixed capital } \\
\text { formation, private sector (\% of } G D P \text { ) }\end{array}$ & WDI \\
\hline$P D$ & Public Debt as percentage of $G D P$ & IMF \\
\hline$P D I_{i t-1}$ & Private investment as a ratio of real $G D P\left(\right.$ lagged $P D I_{i t}$ ) & WDI \\
\hline$G D P_{i t}$ & Gross domestic product growth (\%) & WDI \\
\hline$C P_{i t}$ & Domestic credit to private sector $(\% G D P)$ & WDI \\
\hline$R I N T_{i t}$ & $\begin{array}{l}\text { Real interest rate (\%) is the lending interest rate adjusted for inflation as } \\
\text { measured by the } G D P \text { deflator. }\end{array}$ & WDI \\
\hline$C O R_{i t}$ & Corruption control & WDI \\
\hline$H C_{i t}$ & Human capital Development, proxied by secondary school enrolment & WDI \\
\hline$T R A D E_{i t}$ & Trade as a percentage of $G D P$ (proxy for liberalization) & WDI \\
\hline$I N F_{i t}$ & Inflation ( $G D P$ Deflator) & WDI \\
\hline
\end{tabular}

Note: WDI is world development indicators sourced from World Bank.

Table 2. Descriptive statistics.

\begin{tabular}{cccccc}
\hline Variable & Obs $(\mathrm{N})$ & Mean & Std Dev & Min & Max \\
\hline PDI & 96 & 20.39 & 5.10 & 9.983 & 33.24 \\
$P D$ & 96 & 59.56 & 30.15 & 19.19 & 138.3 \\
COR & 80 & 42.52 & 16.39 & 20.10 & 82.78 \\
$G D P$ & 96 & 5.488 & 7.24 & -50.25 & 35.22 \\
$F D I$ & 96 & 2.150 & 1.82 & 0.000133 & 6.48 \\
$C P$ & 96 & 14.03 & 8.06 & 3.09 & 34.89 \\
$R I N T$ & 93 & 9.247 & 7.33 & -9.74 & 28.66 \\
Trade & 96 & 45.35 & 11.27 & 23.83 & 72.86 \\
$I N F$ & 96 & 11.26 & 10.31 & -9.19 & 51.27 \\
$H C$ & 96 & 2.20 & 2.6 & 0 & 9.01 \\
\hline
\end{tabular}

Source: Author's computation.

Table 3. Pair wise correlation.

\begin{tabular}{cccccccccc}
\hline & $G D P$ & $P D$ & $F D I$ & $R I N T$ & $C O R$ & $C P$ & $H C$ & Trade & $I N F$ \\
\hline$G D P$ & 1 & & & & & & & & \\
$P D$ & 0.058 & 1 & & & & & & & \\
$F D I$ & 0.128 & -0.416 & 1 & & & & & & \\
$R I N T$ & 0.052 & 0.214 & -0.027 & 1 & & & & & \\
$C O R$ & 0.418 & -0.015 & -0.021 & -0.008 & 1 & & & & \\
$C P$ & -0.334 & -0.354 & -0.426 & -0.034 & -0.274 & 1 & & & \\
$H C$ & -0.218 & -0.345 & -0.247 & -0.059 & -0.143 & 0.538 & 1 & & \\
Trade & -0.374 & -0.579 & -0.036 & -0.188 & -0.424 & 0.711 & 0.543 & 11 & 1 \\
$I N F$ & -0.217 & -0.071 & 0.052 & -0.858 & -0.149 & -0.068 & -0.099 & 0.159 & 1 \\
\hline
\end{tabular}

Source: Author's computation based on World Bank WDI and WGI statistics. 


\section{Results and Discussion}

\subsection{Panel Unit Root Test}

Table 4 reports results from the panel unit root tests intended to check for stationarity of data. As evident in the table, the results from the Levin, Lin \& Chu (LLC) test show that $P I, P D, F D I, C O R, C P$ and Trade were all stationary at first difference. Inflation is the only variable that was stationary at level but was stationary at first difference. Human capital is neither stationary at level nor first difference. Also, the LLC test requires that panels are balanced. Since interest rate was unbalanced, the unit root test could not be done on it. On the other hand, the Im Pesaran and Shin (IPS) Test results indicate that all the variables ( $P I, P D, F D I, C O R, R I N T, C P, H C$, Trade, Inflation) are stationary at level. The Panel Unit Root Tests hence indicate that variables meet the requirements of Panel ARDL.

\subsection{Empirical Results}

\subsubsection{Impact of Public Debt on Private Domestic Investment}

In Table 5 we present results of the estimated relationship between Public Debt and Private Domestic Investment by both the Pooled Mean Group and Mean Group estimators of Panel ARDL Model. Due to varied results from the two estimators, it is imperative to select the preferred model using the Hausman test. The null hypothesis under the test is that of slope homogeneity, where accepting

Table 4. Panel Unit root results.

\begin{tabular}{|c|c|c|c|c|c|}
\hline & $\begin{array}{c}\text { LLC } \\
\text { Test (t-statistic) }\end{array}$ & $\begin{array}{c}\text { IPS } \\
\text { Test (t-statistic) }\end{array}$ & $\begin{array}{c}\text { LLC } \\
\text { Test (t-statistic) }\end{array}$ & $\begin{array}{c}\text { IPS } \\
\text { Test (t-statistic) }\end{array}$ & Order \\
\hline & \multicolumn{2}{|c|}{ level } & \multicolumn{2}{|c|}{$1^{\mathrm{ST}}$ Difference } & \\
\hline$P I$ & $\begin{array}{l}-3.084 \\
(0.001)\end{array}$ & $\begin{array}{c}-3.372 \\
(0.0003)\end{array}$ & $\begin{array}{l}-6.7158 \\
(0.0000)\end{array}$ & $\begin{array}{l}-5.7547 \\
(0.0000)\end{array}$ & I (0) \\
\hline$P D$ & $\begin{array}{l}-2.013 \\
(0.022)\end{array}$ & $\begin{array}{l}-2.605 \\
(0.0414)\end{array}$ & $\begin{array}{l}-3.2129 \\
(0.0007)\end{array}$ & $\begin{array}{l}-3.5842 \\
(0.0001)\end{array}$ & I (1) \\
\hline$F D I$ & $\begin{array}{l}-1.382 \\
(0.083)\end{array}$ & $\begin{array}{l}-2.970 \\
(0.0025)\end{array}$ & $\begin{array}{l}-4.6783 \\
(0.0000)\end{array}$ & $\begin{array}{l}-7.1446 \\
(0.0000)\end{array}$ & I (1) \\
\hline$C O R$ & $\begin{array}{l}-2.1544 \\
(0.0156)\end{array}$ & $\begin{array}{c}-2.7539 \\
(0.008)\end{array}$ & $\begin{array}{l}-2.9228 \\
(0.0017)\end{array}$ & $\begin{array}{l}-4.8725 \\
(0.0000)\end{array}$ & I (1) \\
\hline$R I N T$ & & $\begin{array}{l}-4.666 \\
(0.000)\end{array}$ & & $\begin{array}{l}-6.5737 \\
(0.0000)\end{array}$ & $\mathrm{I}(0)$ \\
\hline$C P$ & $\begin{array}{l}-1.9334 \\
(0.0266)\end{array}$ & $\begin{array}{l}-2.1535 \\
(0.0684)\end{array}$ & $\begin{array}{l}-3.2602 \\
(0.0006)\end{array}$ & $\begin{array}{l}-5.0612 \\
(0.0000)\end{array}$ & I (1) \\
\hline$H C$ & $\begin{array}{l}-0.0712 \\
(0.4716)\end{array}$ & $\begin{array}{c}-2.701 \\
(0.0095)\end{array}$ & $\begin{array}{l}-0.9655 \\
(0.1672)\end{array}$ & $\begin{array}{l}-6.3866 \\
(0.0000)\end{array}$ & I (1) \\
\hline Trade & $\begin{array}{l}-3.5859 \\
(0.0002)\end{array}$ & $\begin{array}{l}-4.339 \\
(0.000)\end{array}$ & $\begin{array}{c}-11.8764 \\
(0.0000)\end{array}$ & $\begin{array}{l}-8.1651 \\
(0.0000)\end{array}$ & $\mathrm{I}(0)$ \\
\hline$I N F$ & $\begin{array}{l}-4.8041 \\
(0.0000)\end{array}$ & $\begin{array}{l}-5.189 \\
(0.000)\end{array}$ & $\begin{array}{l}-7.3573 \\
(0.0000)\end{array}$ & $\begin{array}{l}-6.9804 \\
(0.0000)\end{array}$ & I (0) \\
\hline
\end{tabular}

Note: LLC is Levin-Lin-Chiu test; IPS is Im-Pesaran-Shin test; RINT lacks strongly balanced data which is a prerequisite for LLC test; p-values in parenthesis. 
Table 5. Impact of public debt on private domestic investment.

\begin{tabular}{|c|c|c|c|c|c|c|}
\hline \multicolumn{7}{|c|}{ Pooled Mean Group and Mean Group Results } \\
\hline & \multicolumn{2}{|c|}{ PMG } & \multicolumn{2}{|c|}{ Hausman test } & \multicolumn{2}{|c|}{ MG } \\
\hline & Coefficient & Std. Error & h-test & p-value & Coefficient & Std. Error \\
\hline \multicolumn{7}{|c|}{ Long Run } \\
\hline$P D$ & $-0.0687^{\star * *}$ & 0.1164 & & & $-0.129^{* *}$ & 0.0581 \\
\hline$G D P$ & $0.1579^{*}$ & 0.0928 & & & -0.0200 & 0.124 \\
\hline$C P$ & $0.5020^{* * *}$ & 0.0948 & & & $0.798^{* * *}$ & 0.190 \\
\hline$R I N T$ & $-0.1494^{* * *}$ & 0.0419 & & & -0.130 & 0.112 \\
\hline$F D I$ & 0.2886 & 0.3671 & & & 0.439 & 0.349 \\
\hline COR & $0.1034^{\star * *}$ & 0.0243 & & & $0.109^{* *}$ & 0.0693 \\
\hline \multicolumn{7}{|c|}{ Short Run } \\
\hline ECT & $-0.5582^{* * *}$ & 0.0869 & & & $-0.7980^{* * *}$ & 0.0257 \\
\hline$P D$ & 0.0018 & 0.0537 & & & -0.0066 & 0.0921 \\
\hline$G D P$ & 0.1670 & 0.1545 & & & 0.2206 & 0.1857 \\
\hline$R I N T$ & $0.0503^{\star}$ & 0.0269 & & & 0.0702 & 0.0208 \\
\hline$C P$ & 0.1577 & 0.4595 & & & -0.1481 & 0.4066 \\
\hline$F D I$ & -0.2920 & 0.2057 & & & -0.4460 & 0.2597 \\
\hline$C O R$ & 0.0366 & 0.0552 & & & 0.00599 & 0.0376 \\
\hline Hausman test $\left(\chi^{2}\right)$ & & & 2.34 & 0.8860 & & \\
\hline
\end{tabular}

Note: $P D$ (Public Debt), GDP(Gross Domestic Product), $C P$ (Credit to Private Sector), RINT (Real Interest Rate), $F D I$ (Foreign Direct Investment) and COR (Corruption Control). The hausman test with a p-value of 0.8860 is greater than $5 \%$ and informs the choice of PMG over the MG estimator. ${ }^{*},{ }^{* *},{ }^{* *}$ indicate significance at $10 \%, 5 \%$ and $1 \%$ respectively. Source: Author's computation.

the null hypothesis implies that PMG is the preferred estimator, where the estimator restricts Long Run equilibrium between variables to be homogenous across countries or a subset of them. The Hausman test with an h-statistic of 2.34 and a p-value of 0.8860 , which is greater than 5 percent level of significance implies that there is slope homogeneity and that PMG is the preferred estimation model. An important note here is that error correction term (ECT) coefficient of -0.5582 at one percent level of significance, is indicative of a disequilibrium in the previous period being corrected at a speed of 55 per cent to reach a steady state.

In the Short Run, $P D$ is observed not significant whereas in the Long Run both variables attract an inversely relationship. Specifically, a unit increase in $P D$ would decrease $P D I$ by approximately 0.0687 units, which indicates that $P D$ crowds out $P D I$. This confirms the priori expectation and is in line with the findings in [10] [25] and [29]. It can be argued that the long run effects of $P D$, for example, loan repayments, tax increases and implications of poorly done projects are likely felt in the future and may discourage investment in the Long Run. The result is call for governments in East Africa to should reduce the rate 
of borrowing or adjust to productive use of borrowed funds so as to encourage private investment. We purport further that the observed impact of $P D$ on $P D I$ could also be driven by the level of corruption control. We come back to this issue later.

Besides the $P D-P D I$ relationship, Table 5 offers additional interesting findings. For example, Corruption Control (COR) is not significant in the Short Run but positively related to $P D I$ with a coefficient of $(0.1034)$ in the Long Run, at 1 percent level of significance. It can be said observed that an improvement in the control of corruption by one unit would increase PDI by 0.1034 units. Intuitively, as governance improves, $P D I$ is likely to increase. The finding is consistent with [35] who established that corruption discourages investment. Similarly, $G D P$ growth and Credit availability to Private sector $(C P)$ positively impacts $P D I$. This implies that as the economy grows and financial markets develop, the $P D I$ will thrive. A unit increase in $C P$ increases $P D I$ by about 0.502 units. This finding is in line with that of [47] who established that Private Investment was constrained by Credit availability. The cost of capital, measured by the Real Interest Rates negatively affects $P D I$ in the Long Run, whereby, a one percent increase in $R I N T$ results in a decrease in $P D I$ of 5 percent. This is in line with the expectations that when RINT decreases, $P D I$ improves. The Short Run results however show that the increase in RINT does not affect $P D I$. This is in line with [48], who established that increases in interest rates did not affect Private Investment. This is however contrary to what is expected from theory, where real interest rate and $P D I$ are inversely related. Notably, we fail to find evidence from data that $F D I$ significantly affects $P D I$ although the possibility is indismissible given the expected sign associated with the relevant coefficient. Perhaps this could imply difficulty in learning, inability of domestic firms to employ high skilled workers from $F D I$ firms or $F D I$ ideas could be patented making franchising costly for smaller domestic firms.

\subsubsection{Impact of Public Debt on Foreign Direct Investment}

Table 6 presents the results regarding the impact of $P D$ on FDI. As evident, PMG Short Run results, $P D$ is not significant and hence does not affect $F D I$. In the Long Run, all other things held constant, a one percent increase in $P D$ decreases $F D I$ by approximately 4 percent.

From the same table, only inflation, as a measure of the macroeconomic environment, proxied by $G D P$ deflator is significant at 10 percent and has a positive impact on $F D I$ in the Short Run. In the Long run, in line with the expectation, inflation is found to negatively influence FDI. Perhaps once viewed as a future cost of investment inflation enters the investors' objective function as a policy variable that measures policy soundness that governments and central banks undertake and therefore the marginal effect of inflation on $F D I$ is observed negative.

Corruption control $(C O R)$ is neither significant in the Short Run nor in the Long Run. This could imply that institutions of host countries do not matter for 
Table 6. Impact of public debt on foreign direct investment.

\begin{tabular}{|c|c|c|c|c|}
\hline & \multicolumn{2}{|l|}{ PMG } & \multicolumn{2}{|l|}{ MG } \\
\hline & Coefficient & Std. Error & Coefficient & Std. Error \\
\hline \multicolumn{5}{|c|}{ Long Run results } \\
\hline$P D$ & $-0.0409^{\star * *}$ & 0.0108 & -0.0266 & 0.0307 \\
\hline$C O R$ & -0.0171 & 0.0202 & 0.0543 & 0.0635 \\
\hline$G D P$ & 0.1499 & 0.1020 & 0.0183 & 0.1104 \\
\hline$H C$ & 0.0471 & 0.0852 & 0.0530 & 0.2728 \\
\hline Trade & -0.0705 & 0.0434 & 0.0676 & 0.1906 \\
\hline$I N F$ & $-0.0658^{\star *}$ & 0.0313 & $-0.0813^{\star *}$ & 0.0409 \\
\hline \multicolumn{5}{|c|}{ Short Run Results } \\
\hline ECT & $-0.6426^{\star * *}$ & 0.2106 & $-1.0002^{\star * *}$ & 0.0363 \\
\hline$P D$ & -0.0104 & 0.0109 & -0.0058 & 0.0197 \\
\hline$C O R$ & 0.0130 & 0.0212 & -0.0055 & 0.0482 \\
\hline$G D P$ & $-0.0538^{* * *}$ & 0.0114 & -0.0605 & 0.0484 \\
\hline$H C$ & 0.0188 & 0.0864 & 0.0225 & 0.1904 \\
\hline Trade & 0.0072 & 0.0373 & -0.1082 & 0.0994 \\
\hline$I N F$ & $0.0245^{\star}$ & 0.0132 & 0.0665 & 0.0499 \\
\hline
\end{tabular}

Note: $P D$ (Public Debt), COR (Corruption Control), GDP (Gross Domestic Product), HC (Human Capital), INF (Inflation), ECT (Error Correction Term); ${ }^{*}{ }^{* *},{ }^{* * *}$ indicate significance at $10 \%, 5 \%$ and $1 \%$ respectively. Source: Author's computation.

FDIs. This is consistent with the findings in [49], where host-country institutions have little support for FDI.

4.2.3. Assessing the Influence of Corruption Control on the PD-PDI Nexus Table 7 addresses the third specific objective, i.e. investigating the influence of corruption control on the $P D-P D I$ Nexus. It is clear from the results that once public debt is interacted with corruption-control in order to factor in institutional quality, the relevant interaction coefficient is positive (0.005) and greater than $P D$ coefficient in the short run. By implication, a one unit increase in $P D$ leads to an increase in $P D I$ as institutional quality grows with it. Note that the marginal change in $P D I$ as $P D$ debt grows, taking into account corruption control, is given by $\alpha_{2}+\alpha_{8} C O R$. In the Short Run, $\alpha_{2}$ which is the $P D$ coefficient is $-0.257, \alpha_{8}$ which is the coefficient of interaction is 0.00515 and $C O R$ which is the mean of corruption is 42.52 . Therefore the marginal impact will be -0.038 [i.e. replacing values into the formula, $-0.257+(0.00515)(42.52)]$. The figure -0.038 indicates a decrease in the impact of $P D$ on $P D I$, with corruption control taken into account. Impact on $P D$ on $P D I$ without interaction is -0.0687 .

The Long Run total impact of $P D$ on $P D I$ in the presence of an improving institutional environment from $\mathrm{PMG}$ regression turns out to be is 42.52 (i.e. 0.155 $+[(-0.00388)(42.52)])$. It can be noted that the impact of $P D$ on $P D I$, when 
Table 7. The impact of institutions on private domestic investment.

\begin{tabular}{|c|c|c|c|c|c|c|}
\hline \multicolumn{7}{|c|}{ Pooled Mean Group and Mean Group Results } \\
\hline \multicolumn{5}{|c|}{ PMG } & \multicolumn{2}{|c|}{ MG } \\
\hline & Coefficient & Std. Error & h-test & p-value & Coefficient & Std. Error \\
\hline \multicolumn{7}{|c|}{ Long Run Results } \\
\hline$P D$ & $0.155^{\star \star \star}$ & 0.0342 & & & -0.117 & 0.387 \\
\hline$G D P$ & $0.247^{\star * *}$ & 0.0237 & & & -0.221 & 0.307 \\
\hline$C P$ & $0.343^{* * *}$ & 0.0584 & & & $0.807^{\star *}$ & 0.355 \\
\hline RINT & $0.830^{* * *}$ & 0.0775 & & & $0.111^{*}$ & 0.064 \\
\hline$F D I$ & $-0.774^{\star * \star}$ & 0.218 & & & $-0.989^{* * *}$ & 0.354 \\
\hline COR & $-0.166^{* * *}$ & 0.0229 & & & 0.117 & 0.526 \\
\hline$P D \times C O R$ & $-0.004^{* * *}$ & 0.0006 & & & 0.002 & 0.009 \\
\hline \multicolumn{7}{|c|}{ Short Run Results } \\
\hline ECT & $-0.634^{* *}$ & 0.217 & & & $-0.987^{\star}$ & 1.409 \\
\hline$P D$ & $-0.257^{\star *}$ & 0.120 & & & 0.0691 & 0.651 \\
\hline$G D P$ & 0.0762 & 0.190 & & & 0.291 & 0.274 \\
\hline RINT & 0.0544 & 0.0210 & & & -0.0834 & 0.150 \\
\hline$C P$ & 0.0593 & 0.408 & & & -0.558 & 0.495 \\
\hline$F D I$ & -0.502 & 0.390 & & & 1.352 & 1.490 \\
\hline COR & -0.304 & 0.272 & & & $-1.117^{\star \star}$ & 0.472 \\
\hline$P D \times C O R$ & 0.005 & 0.004 & & & $0.009^{* * *}$ & 0.003 \\
\hline Hausman test $\chi^{2}$ & & & 2.34 & 0.8860 & & \\
\hline
\end{tabular}

Note: ${ }^{*},{ }^{* *},{ }^{* *}$ indicate significance at $10 \%, 5 \%$ and $1 \%$ respectively. Source: Author's computation.

factoring in corruption $(-0.01)$ is less than -0.0687 (impact of debt without factoring in institutions as in Table 5). Therefore, from the short run and Long Run PMG results, the impact of institutions proxied by corruption control supports the hypothesis that good institutions matter for Private Domestic Investment. Corruption control would imply a reduction in use of public authority for private gains, low cost of investment and efficient mobilization and use of public resources that would lead to a reduction in debt levels. Moreover, when governance levels improve, the capture of the state by the elite decreases and small scale private domestic investors could also be awarded contracts based on merit and not by influencing public officers [20]. Furthermore, with good governance, public projects that compliment $P D I$ will be executed efficiently.

\subsubsection{Corruption, Public Debt and FDI}

Table 8 reports our findings regarding the link among corruption, $P D$ and $F D I$. In the upper panel, the marginal impact of $P D$ on $F D I$ in the presence of institutional quality is about 42.52 (i.e. -0.033384$)$ (i.e. $-0.1731+[(0.0033)(42.52)]$ ). Since the coefficient of the interaction term is positive (0.0033) and the absolute 
Table 8. Assessing impact of public debt and corruption on foreign direct investment.

\begin{tabular}{|c|c|c|c|c|}
\hline & \multicolumn{2}{|c|}{ PMG } & \multicolumn{2}{|c|}{ MG } \\
\hline & Coefficient & Std. Error & Coefficient & Std. Error \\
\hline \multicolumn{5}{|c|}{ Long Run Results } \\
\hline$P D$ & $-0.1731^{\star * *}$ & 0.0447 & -0.4739 & 0.5821 \\
\hline$C O R$ & $-0.1172^{\star * *}$ & 0.0423 & -0.7133 & 0.9541 \\
\hline$G D P$ & 0.1559 & 0.1079 & -0.1896 & 0.3283 \\
\hline$H C$ & 0.0353 & 0.08754 & -0.3268 & 0.5505 \\
\hline Trade & $-0.1182^{\star * *}$ & 0.0364 & 0.1652 & 0.1480 \\
\hline$I N F$ & $-0.1228^{\star * *}$ & 0.0384 & -0.0408 & 0.0408 \\
\hline$P D \times C O R$ & $0.0033^{* * *}$ & 0.0011 & 0.0143 & 0.0175 \\
\hline \multicolumn{5}{|c|}{ Short Run Results } \\
\hline ECT & $-1.09^{\star * *}$ & 0.2240 & $-1.3009^{* * *}$ & 0.8778 \\
\hline$P D$ & -0.0982 & 0.0880 & -0.0308 & 0.3053 \\
\hline$C O R$ & -0.0959 & 0.1548 & 0.2205 & 0.364 \\
\hline$G D P$ & -0.0664 & 0.0346 & $0.389^{*}$ & 0.2122 \\
\hline$H C$ & -0.0177 & 0.0188 & 1.2495 & 1.4532 \\
\hline Trade & -0.0181 & 0.0220 & -0.365736 & 0.3718 \\
\hline$I N F$ & $0.0440^{*}$ & 0.0231 & $0.1231^{\star}$ & 0.0710 \\
\hline$P D \times C O R$ & 0.0010 & 0.0023 & -0.0017 & 0.0055 \\
\hline
\end{tabular}

Note: ${ }^{*},{ }^{* *}{ }^{* *}$ indicate significance at $10 \%, 5 \%$ and $1 \%$ respectively. Source: Author's computation.

value exceeds coefficient of $P D(-0.1731)$, it implies that a one percent increase in $P D$ yields an improvement on $F D I$ as institutional quality grows with it. Therefore, the impact of institutions proxied by corruption-control supports the hypothesis that good institutions matter for Foreign Direct Investment. Intuitively, corruption reduces Foreign Direct Investment, a finding consistent with [33] and [34]. The result is augmented in the short run PMG model where the interaction term is positive (0.0010), implying that corruption-control could improve $F D I$.

\subsubsection{Non-Linearity of Public Debt on Private Investment}

Table 9 confirms our earlier finding of the adverse effect of public debt on private investment. However, this relationship is shown to be non-linear, as evident first order optimal outcome of public debt. The change of sign from a significantly negative to positive on the associated coefficients of the unsquared and squared debt variables respectively affords us the conclusion of a U-shaped curve. The finding is consistent with earlier submission in [11]. Additionally, there is threshold level identified here. Specifically, the debt-effect is expectedly negative until a threshold of about $94.93 \%$ of $G D P$ when thereafter it starts to be beneficial to private investment in the East African countries under analysis. 
Table 9. ARDL Panel Results on debt sustainability.

\begin{tabular}{ccccc}
\hline$P D I$ (Dependent Variable) & Coefficient & Std Error & p-value & Z-Statistic \\
\hline$P D$ & -0.4317 & 0.0833 & 0.000 & -5.18 \\
$P D^{\wedge} 2$ & 0.0023 & 0.0006 & 0.000 & 3.60 \\
$P D$ Turning point & 94.93 & & & \\
$F D I$ (Dependent variable) & & & & \\
$F D$ & -0.0192912 & .0140124 & 0.169 & -1.38 \\
$F D^{\wedge} 2$ & -0.0000669 & .0001058 & 0.527 & -0.63 \\
\hline
\end{tabular}

Note: A constant is included in each model. The threshold or turning point is calculated using equation (18) in the text. Source: Author's computation.

Implicitly, for public debt to have a positive impact on private investment, borrowed amounts must be invested productively and in a manner that is private-sector-enhancing or else the impact of debt on private investment may always be negative.

However, given the popular argument shared by [50] and [51] inter alia, that thresholds are sensitive to the time dimension, the variables used, the set of countries under consideration together with their economic characteristics, the threshold level reported here ought to be interpreted with caution. On the other hand, we fail to find evidence that the relationship between public debt and FDI is non-linear. The associated signs on the relevant coefficients potentially confirm a linear type of relationship.

\subsection{Robustness Checks}

In order to check the validity of our study, we conduct several robustness checks. First, we carried out a country-by-country analysis allowed by the ARDL technique. Since the results do not substantially alter the original findings, and due to space limitations, we do not present them here but they are available on request. Second, we adopted a common practice in several empirical works of using three-year averages of all the variables to eliminate short run fluctuations. Here we notice a few ignorable changes that do not seriously alter interpretation of the original findings. Similarly, one would perhaps argue that the findings could be driven by the existence of more or less developed economies in East Africa in relation to their counterparts. We therefore dropped Kenya from the sample. In turn, we also dropped Rwanda to remain with the original EAC countries. Later we also dropped the most corrupt country just as we in turn dropped the country with the largest public debt on average during the study period. Unsurprisingly, the results were never substantially affected in each of the "droppings", although some control variables turned out more significant. Given the high similarity rate with the original findings, still we have spared space and not presented the robustness results here but they are available on request.

\section{Concluding Remarks}

The study analyzed the relationship between Public Debt and Private Domestic 
Investment and also investigated the impact of $P D$ on $F D I$ in the EAC countries. The findings indicate a crowding out effect of Public Debt. It is further noted that the magnitude of the Public Debt's impact is greater for PDI as compared to FDI. Additionally, it appears that interaction of public debt and corruption control improves Private Investment in the Long run. This has the implication that enhancing of institutional quality is vital in the promotion and development of Private Investment. Our findings also point to a nonlinear relationship between public debt and domestic investment. The results for a panel of the 4 East African countries over the period 1992-2015, indicate that public debt lower than 94.93 percent of $G D P$ is positively associated with private domestic investment. Otherwise, once the debt exceeds this threshold, the relationship between public debt and investment becomes negative.

The results from the study have policy implications. The immediate recommendation is the need to design fiscal policies to tame the growing debt that discourages private investment. In addition to the urgent necessity to reduce reliance on non-concessional borrowing in refinancing the debt and lowering fiscal vulnerabilities, there is need for a proper debt management system to lower fiscal vulnerabilities, coupled with clear policies to improve the institutional quality in order to boost private investment in East Africa. Any existing fiscal adjustment efforts that are focused on both expenditures and revenues together with complimentary monetary policies deserve commendation. Also, the anti-corruption measures already in place and those in the pipeline should be strongly supported to create a conducive investment climate for the private sector to thrive.

Besides the policy implications, the study appears to have insinuated further debate in related areas. For example, the finding of an insignificant relationship between FDI and PDI may not be taken on face value. Perhaps, it would be interesting to find out the empirical rationale behind such an outcome in at a more detailed level regarding FDI spillover effects. A related area of interest but which was outside the scope of our study is decomposing private investment by category and taking them as separate dependent variables. Perhaps such an analysis would provide a more detailed picture of the debt-investment link. However, such a kind of analysis would be limited by data availability. A similar limitation is likely a hindrance to repeating the analysis by disaggregating public debt in order to determine which category of debt impacts greatly on investment. Otherwise once data gets available in future, such would be an interesting area to better understand the debt-investment nexus.

\section{Conflicts of Interest}

The authors declare no conflicts of interest regarding the publication of this paper.

\section{References}

[1] Bazaumana, O. (2004) Modeling the Long Run Determinants of Private Investment 
in Senegal. Centre for Research in Economic Development and International Trade (CREDIT), No.04/05, University of Nottingham, Nottingham, 1-23.

[2] Majumder, A. (2007) Does Public Borrowing Crowd-Out Private Investment? The Bangladesh Evidence. Policy Analysis Unit, Bangladesh Bank.

[3] Oche, M.O, Mah, G. and Mongale, I. (2016) The Effect of Public Debt on Foreign Direct Investment in South Africa (1983-2013): An Empirical Analysis. Risk Governance and Control: Financial Markets and Institutions, 6, 448-456. https://doi.org/10.22495/rgcv6i4siart2

[4] Khan, R.E.A and Gill, A.R. (2009) Crowding Out Effect of Public Borrowing: A Case of Pakistan. University Library of Munich, München.

[5] Kumar, M.S. and Woo, J. (2015) Public Debt and Growth. IMF Working Paper No. 10/174, Economica, 82, 705-739.

[6] Huang, Y., Pagano, M. and Panizza, U. (2016) Public Debt and Private Firm Funding: Evidence from Chinese Cities. CEPR Discussion Paper No. DP11489. https://ssrn.com/abstract=2834826

[7] Huang, Y., Panizza, U. and Varghese, R. (2018) Does Public Debt Crowd Out Corporate Investment? International Economics Department Working Paper HEIDWP08-2018, The Graduate Institute, Geneva.

[8] Paiko, I.I. (2012) Deficit Financing and Its Impacts on Private Sector Investment: The Nigerian Experience. Arabian Journal of Business and Management Review (Oman Chapter), 1, 45-62. https://doi.org/10.12816/0002187

[9] Azam, M. and Khan, A. U. (2011) Impact of Public Debt on Foreign Direct Investment in Pakistan: A Quantitative Approach. Elixir Financial Management, 38, 4225-4227.

[10] Benayed, W., Gabsi, F.B. and Belguith, S.O. (2015) Threshold Effect of Public Debt on Domestic Investment: Evidence from Selected African Countries. Theoretical and Applied Economics, 22, 189-198.

[11] Apere, T.O. (2014) The Impact of Public Debt on Private Investment in Nigeria: Evidence from a Nonlinear Model. International Journal of Research in Social Sciences, 4, 130-138.

[12] Khan, H.N, Khawar, M. and Khan, I. (2014) Effect of Public Debt on Economic Growth, Investment and Unemployment. Blog at WordPress.Com. https://hiranisarkhanhnk.wordpress.com/2014/06/21/effect-of-public-debt-on-econ omic-growth-investment-and-unemployment/

[13] IMF (2016) Kenya: Second Review Under the Stand-By Arrangement and the Arrangement under the Standby Credit Facility, and Requests for a New Twenty-Four Month Stand-By Arrangement, and a New Twenty-Four Month Arrangement under the Standby Credit Facility—Debt Sustainability Analysis Update.

[14] Angualia, D. (2010) Foreign Direct Investment in East Africa. A Comparative Analysis of Its Investment Laws. https://ssrn.com/abstract=1593731

[15] Ernst, M. and Young (2016) Africa Attractiveness Program Report, Ernst and Young. https://en.wikipedia.org/wiki/Gross_private_domestic_investment

[16] WEF (2015) The Future of Manufacturing: Driving Capabilities, Enabling Investments. WEF, Davos.

http://www3.weforum.org/docs/Media/GAC14/Future_of_Manufacturing_Driving CCapabilities.pdf

[17] Spyros, K.L. (1983) Investment Behavior in a Nationalized Industry. Applied Economics, 15, 665-679. https://doi.org/10.1080/00036848300000043 
[18] Clark, J.M. (1917) Business Acceleration and the Law of Demand: A Technical Factor in Economic Cycles. Journal of Political Economy, 25, 217-235.

[19] Akkina, K.R. and Celebi, M.A. (2002) The Determinants of Private Fixed Investment and the Relationship between Public and Private Capital Accumulation in Turkey. The Pakistan Development Review, 41, 243-254. https://doi.org/10.30541/v41i3pp.243-254

[20] Bbale, J.M. and Nnyanzi, J.B. (2016) How Do Liberalization, Institutions and Human Capital Development Affect the Nexus between Domestic Private Investment and Foreign Direct Investment? Evidence from Sub-Saharan Africa. Global Economy Journal, 16, 569-598. https://doi.org/10.1515/gej-2015-0057

[21] Jorgenson, D. (1967) Determinants of Investment Behavior. National Bureau of Economic Research. http://www.nber.org/chapters/c1235

[22] Tobin, J. (1969) A General Equilibrium Approach to Monetary Theory. Journal of Money, Credit and Banking, 1, 15-29. https://doi.org/10.2307/1991374

[23] Twine, E., Kiiza, B. and Bashaasa, B. (2015) The Flexible Accelerator Model of Investment: An Application to Ugandan Tea-Processing Firms. African Journal of Agricultural and Resource Economics, 10, 1-15.

[24] Eklund, J.E. (2013) Theories of Investment: A Theoretical Review with Empirical Applications. Working Papers Series from Swedish Entrepreneurship Forum, Working Paper, 22.

[25] Metwally and Tamaschke (1994) Debts and Deficit Ceilings, and Sustainability of Fiscal Policies: An Intertemporal Analysis. Oxford Bulletin of Economics and Statistics, 62, 197-221.

[26] Oke, M.O. and Sulaiman, L.A. (2012) External Debt, Economic Growth and Investment in Nigeria. European Journal of Business and Management, 4, 67-75.

[27] Matwang'a, L.F. (2000) Determinants and Constraints to Private Investment: The Case of Kenya. African Institute for Economic Development and Planning, Dakar.

[28] King'wara, R. (2014) The Impact of Domestic Public Debt on Private Investment in Kenya. Developing Country Studies, 4, 92-96.

[29] Kamundia, S.W., Gitahi, G. and Mwilaria, S.M. (2015) The Effects of Public Debt on Private Investment in Kenya. International Journal of Development and Sustainability, 4, 860-871.

[30] Thilanka, H.R. and Sri Ranjith, J.G. (2018) The Impact of Public Debt on Private Investment: Sri Lankan Experience. International Journal of Business and Social Research, 8, 1-10.

[31] Akomolafe, K.J., Bosede, O., Oni, E. and Achukwu, M. (2015) Public Debt and Private Investment in Nigeria. American Journal of Economics, 5, 501-507.

[32] Shah, M.H. and Pervin, S. (2012) External Public Debt and Economic Growth: Empirical Evidence from Bangladesh, 1974-2010. Academic Research International, 3, $1-8$.

[33] Abed, G.T. and Davoodi, H.R. (2000) Corruption, Structural Reforms and Economic Performance in the Transition Economies. IMF Working Paper.

[34] Wei, S.J. (2000) How Taxing Is Corruption on International Investors? The Review of Economics and Statistics, 82, 1-11. https://doi.org/10.1162/003465300558533

[35] Brunetti, A., Kisunko, G. and Weder, B. (1998) Credibility of Rules and Economic Growth: Evidence from a Worldwide Survey of the Private Sector. World Bank Economic Review, 12, 353-384. https://doi.org/10.1093/wber/12.3.353 
[36] Latruffe, L. (2004) Investment and Financial Constraints of Polish Farmers. INRA-Unite ESR Working Paper.

[37] Afonso, A. and Alves, J.R. (2015) The Role of Government Debt in Economic Growth. Hacienda Pública Española IEF, 215, 9-26.

[38] Checherita, C. and Rother, P. (2010) The Impact of High and Growing Government Debt on Economic Growth an Empirical Investigation for the Euro Area. European Central Bank.

[39] Arellano, M. and Bond, S. (1991) Some Tests of Specification for Panel Data: Monte Carlo Evidence and an Application to Employment Equations. Review of Economic Studies, 58, 277-297. https://doi.org/10.2307/2297968

[40] Blundell, R. and Bond, S. (1998) Initial Conditions and Moment Restrictions in Dynamic Panel Data Models. Journal of Econometrics, 87, 115-143. https://doi.org/10.1016/S0304-4076(98)00009-8

[41] Alam, M.I. and Quazi, R.M. (2003) Determinants of Capital Flight: An Econometric Case Study of Bangladesh. International Review of Applied Economics, 17, 85-103. https://doi.org/10.1080/713673164

[42] Siddik, J.U. (2000) Demand for Money in Bangladesh: A Cointegration Analysis. Applied Economics, 32, 1977-1984. https://doi.org/10.1080/00036840050155904

[43] Siddiki, J.U. (2002) Trade and Financial Liberalization and Endogenous Growth in Bangladesh. International Economic Journal, 16, 23-37.

https://doi.org/10.1080/10168730200000019

[44] Almasaied, S.W. (2007) The Impact of Investment and Financial Intermediation on Economic Growth: New Evidence from Jordan. Arab Journal of Administrative Science.

[45] Khatib, H.B., Altaleb, G.S. and Alokor, S.M. (2016) Economical Determinants of Domestic Investment. European Scientific Journal, 8, 1-17.

[46] Pesaran, M.H. and Shin, Y. (1995) Long-Run Structural Modeling. University of Cambridge, Cambridge.

[47] Erden, L. and Holcombe, R.G. (2005) The Effects of Public Investment on Private Investment in Developing Economies. Finance Review, 33, 575-602. https://doi.org/10.1177/1091142105277627

[48] Kariuki, D.K. (2003) Determinants of Fixed Capital Formation in Kenya. M.A. Thesis, Makerere University, Kampala.

[49] Blonigen, B.A. and Piger, J. (2011) Determinants of Foreign Direct Investment. NBER Working Paper No. 16704. https://doi.org/10.3386/w16704

[50] Panizza, U. and Presbitero, A. (2012) Public Debt and Economic Growth: Is There a Causal Effect? MoFiR Working Paper No. 65.

[51] Égert, B. (2015) Public Debt, Economic Growth and Nonlinear Effects: Myth or Reality? Journal of Macroeconomics, 43, 226-238. https://doi.org/10.1016/j.jmacro.2014.11.006 